\title{
Correction to: Cytoplasm protein GFAP magnetic beads construction and application as cell separation target for brain tumors
}

\author{
Yang Zhao ${ }^{1 \dagger}$, Feng Jiang ${ }^{1 \dagger}$, Qinhua Wang ${ }^{1 \dagger}$, Baocheng Wang ${ }^{1}$, Yipeng Han ${ }^{1}$, Jian Yang ${ }^{1}$, Jiajia Wang ${ }^{1}$, Kai Wang ${ }^{2}$, \\ Junping $\mathrm{Ao}^{2}$, Xunxiang $\mathrm{GuO}^{3}$, Xiaofei Liang ${ }^{2,3^{*}}$ and Jie $\mathrm{Ma}^{1^{*}}$
}

\section{Correction to: J Nanobiotechnol 18:169 (2020) https://doi.org/10.1186/s12951-020-00729-9}

Following publication of the original article [1], the authors identified an inadvertent error. Figure $2 \mathrm{f}$ and e were partially duplicated, an error which was possibly made during image compilation. It is therefore necessary to correct Fig. 2f. The corrected Figure $2 \mathrm{f}$ and figure caption are given below. The correction of this figure does not affect the results and conclusion. All authors agree to this correction and apologize for this error. The original full field view of Figure $2 \mathrm{f}$ is also provided in supplementary information Fig S1.

The authors alsofound that the cells in the left three columns (the last row of Fig. 3) were inconsistent with those in the right three columns. In order to facilitate the readers' understanding of that part of the content and avoid any possible confusion, we hereby provide the cells consistent with the right three columns as a supplement. The supplementary pictures are shown below in Fig. 3 (the last row). The original full field view of the last row of Fig. 3 is also provided in supplementary information Fig S2.

In summary, we provide a correction of Figure $2 \mathrm{f}$ and a supplementary image for the last row of Fig. 3 as follows:

1. The correction of Fig. 2f:

(See figure on next page.)

Fig. 2 Material characteristics of the three IMLs. a Protein electrophoresis. Lanes 1-3 were GFAP, GFAP-GHDC, and GFAP-IMLs, respectively; b UV spectra. Lines 1-4 indicate the GFAP, GFAP-GHDC, $\mathrm{Fe}_{3} \mathrm{O}_{4}$ raw magnetic beads and GFAP-IMLs; c Raman spectra. Lines 1-3 indicate the GFAP, GFAP-GHDC, and GFAP-IMLs; d VSM magnetization curves. Lines 1-3 demonstrate the Fe3O4 raw magnetic beads, magnetic liposomes, and antibody-IMLs, respectively. e Upper: AFM topographic image and below: particle size distribution of GFAP-IMLs; f Upper: AFM topographic image and below: particle size distribution of EpCAM-IMLs; $\mathbf{g}$ Upper: AFM topographic image and below: particle size distribution of EGFR-IMLs

The original article can be found online at https://doi.org/10.1186/s12951020-00729-9.

\footnotetext{
*Correspondence: xfiang@shsci.org; majie@xinhuamed.com.cn

${ }^{\dagger}$ Yang Zhao, Feng Jiang and Qinhua Wang contributed equally to this work

${ }^{1}$ Department of Pediatric Neurosurgery, Shanghai Xin Hua Hospital Affiliated To Shanghai Jiaotong University, School of Medicine, No. 1665 Kongjiang Road, Shanghai 200092, China

2 State Key Laboratory of Oncogenes and Related Genes, Shanghai Cancer Institute, Renji Hospital, Shanghai Jiaotong University School of Medicine, No. 25/Ln 2200 Xie Tu Road, Shanghai 200032, China Full list of author information is available at the end of the article
} permits use, sharing, adaptation, distribution and reproduction in any medium or format, as long as you give appropriate credit to the original author(s) and the source, provide a link to the Creative Commons licence, and indicate if changes were made. The images or other third party material in this article are included in the article's Creative Commons licence, unless indicated otherwise in a credit line to the material. If material is not included in the article's Creative Commons licence and your intended use is not permitted by statutory regulation or exceeds the permitted use, you will need to obtain permission directly from the copyright holder. To view a copy of this licence, visit http://creativecommons.org/licenses/by/4.0/. The Creative Commons Public Domain Dedication waiver (http://creativecommons.org/publicdomain/zero/1.0/) applies to the data made available in this article, unless otherwise stated in a credit line to the data. 

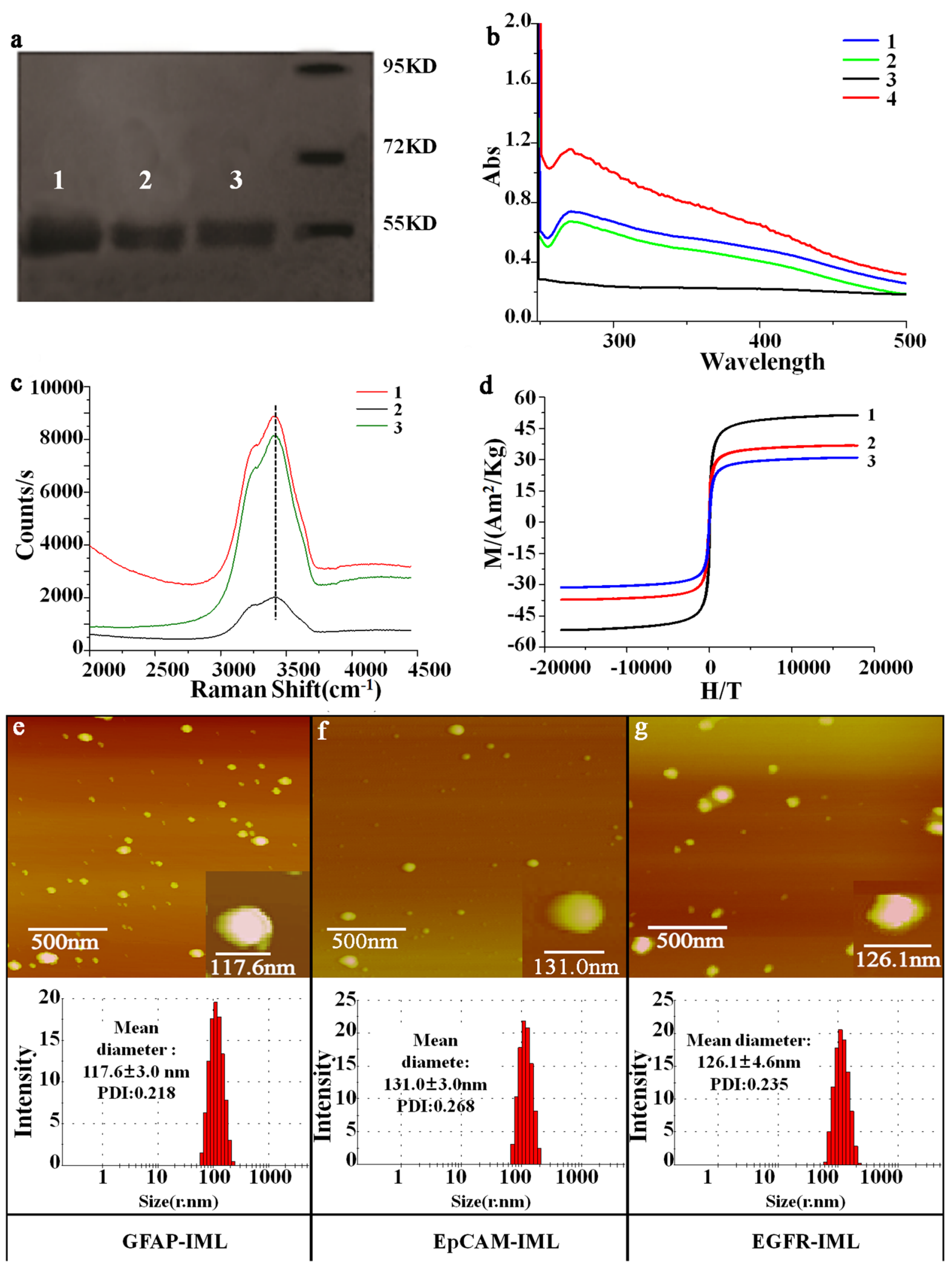

Fig. 2 (See legend on previous page.) 
Supplementary information Fig S1:

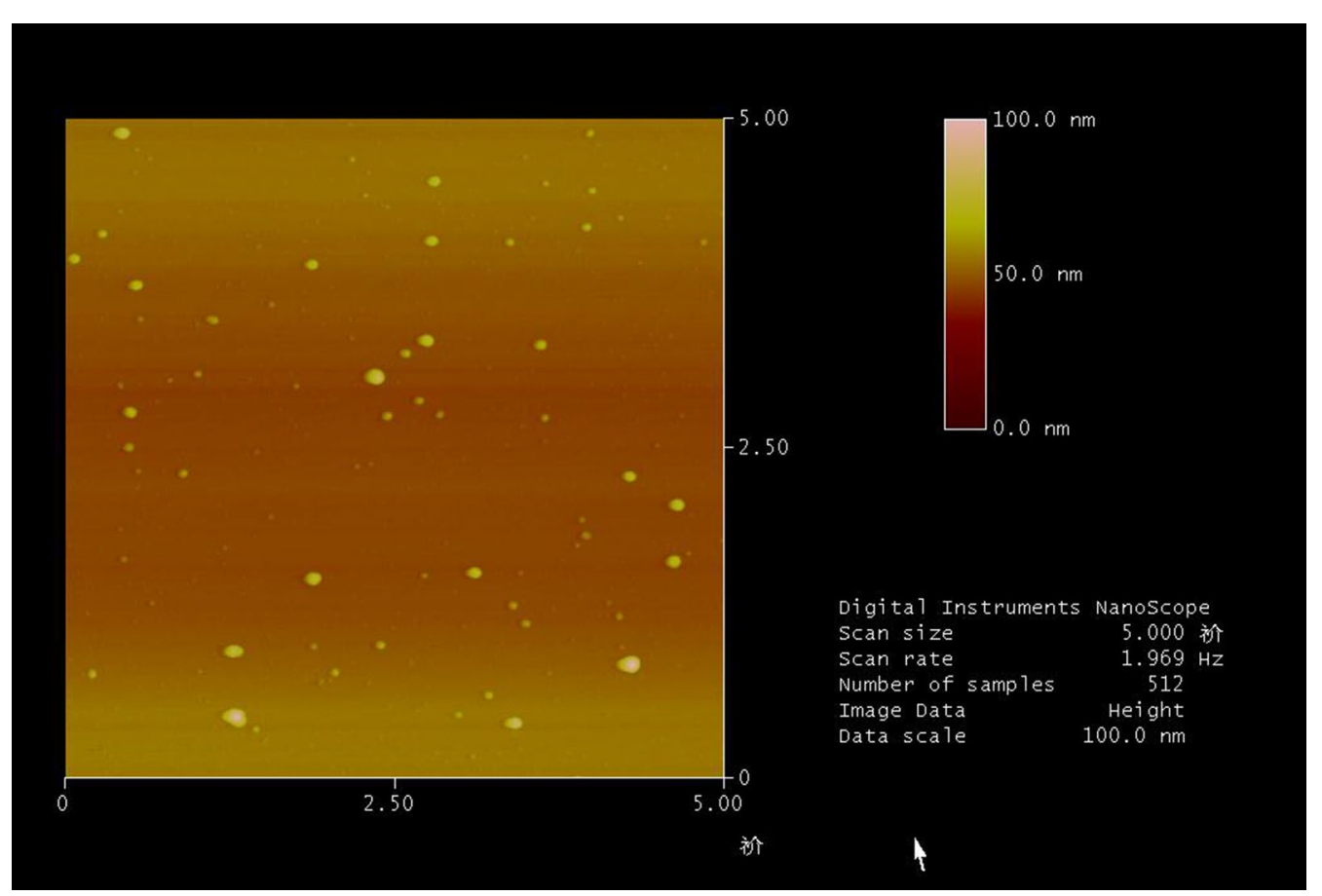

2. The supplementary image for Fig. 3 (the last row):

\begin{tabular}{|c|c|c|c|c|c|}
\hline WF & Dil & DAPI & GFAP-FITC & Merge & Dil+FITC \\
\hline $30 \mathrm{~min}$ & $30 \mathrm{~min}$ & $30 \mathrm{~min}$ & $30 \mathrm{~min}$ & $30 \mathrm{~min}$ & $30 \mathrm{~min}$ \\
\hline $20.0 \mu \mathrm{m}$ & $20.0 \mu \mathrm{m}$ & $20.0 \mu \mathrm{m}$ & $20.0 \mu$ & $20.0 \mu \mathrm{m}$ & $20.0 \mu \mathrm{m}$ \\
\hline
\end{tabular}

Supplementary information Fig S2:

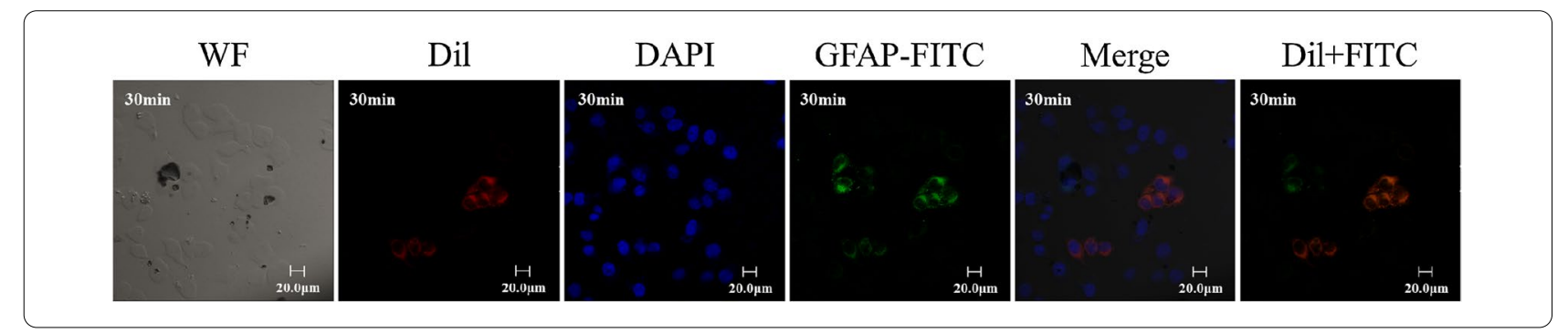


The authors apologize for these errors and any inconvenience to the reader.

\section{Author details}

${ }^{1}$ Department of Pediatric Neurosurgery, Shanghai Xin Hua Hospital Affiliated To Shanghai Jiaotong University, School of Medicine, No. 1665 Kongjiang Road, Shanghai 200092, China. ${ }^{2}$ State Key Laboratory of Oncogenes and Related Genes, Shanghai Cancer Institute, Renji Hospital, Shanghai Jiaotong University School of Medicine, No. 25/Ln 2200 Xie Tu Road, Shanghai 200032, China. ${ }^{3}$ Key Laboratory of Systems Biomedicine (Ministry of Education), Shanghai Center for Systems Biomedicine, Shanghai Jiao Tong University, Shanghai 200240, China.

Published online: 18 October 2021

\section{Reference}

1. Zhao Y, Jiang F, Wang Q, Wang B, Han Y, Yang J, Wang J, Wang K, Ao J, Guo $X$, Liang $X$, Ma J. Cytoplasm protein GFAP magnetic beads construction and application as cell separation target for brain tumors. J Nanobiotechnol. 2020;18(1):169. https://doi.org/10.1186/s12951-020-00729-9.

\section{Publisher's Note}

Springer Nature remains neutral with regard to jurisdictional claims in published maps and institutional affiliations. 